\title{
Petrographic observations suggestive of microbial mats from Rampur Shale and Bijaigarh Shale, Vindhyan basin, India
}

\author{
S SUR ${ }^{1, *}, \mathrm{~J} \mathrm{SCHIEBER}^{2}$ and S BANERJEE ${ }^{3}$ \\ ${ }^{1}$ Department of Geology and Geophysics, The University of Oklahoma, 100 East Boyd St., \\ SEC Suite 810, Norman OK 73019, U.S.A. \\ ${ }^{2}$ Department of Geological Sciences, Indiana University, 1001 E 10th St., Bloomington, IN 47405, U.S.A. \\ ${ }^{3}$ Department of Earth Sciences, Indian Institute of Technology Bombay, Mumbai 400 076, India. \\ *e-mail:ssur@ou.edu
}

Petrographic observations of two Vindhyan black shales (Rampur Shale of the Semri Group and Bijaigarh Shale of the Kaimur Group) revealed the following features:

- general wavy lamination,

- contorted and folded thin shreds of organic matter,

- wavy pyritic laminae,

- 'teeth and socket' structure.

These features are indirect evidence of microbial mat colonization during the Proterozoic. The microbial mats probably fixed carbon at the sediment surface, stabilized sediment and recycled organic matter and were the primary producers, unlike during the Phanerozoic time.

\section{Introduction}

Microbially mediated sedimentation is well known from Precambrian carbonates. In the absence of metazoans microbial mats flourished in Precambrian seas, and in turn played a major role in sedimentation. The importance of microbial mats in siliciclastic sedimentation, preservation and modifying sediment surface is being increasingly recognized (e.g., Schwarz et al 1975; Seilacher and Pflüger 1994; Hagadorn et al 1999; Schieber 1999; Pflüger 1999; Gehling 1999; Schieber 2004; Sarkar et al 2005). Though these mats were considered to be ubiquitous during the Precambrian, the problem with their identification in the rock record remains. Many of the microbial features get erased because of later metamorphism and diagenesis. However, the Paleoproterozoic to Neoproterozoic Vindhyan sedimentary succession is almost unmetamorphosed and less deformed. It provides an excellent opportunity to study the microbial mat features. However, only a few authors have addressed microbially induced sedimentary structures from the Vindhyan sedimentary succession (Banerjee and Schieber 2003; Sarkar et al 2004; Sarkar et al 2005; Banerjee and Jeevankumar 2005). In the present paper an attempt has been made to highlight possible microbial mat features from two black shale horizons (Rampur Shale and Bijaigarh Shale) of the Vindhyan Supergroup based on petrographic observations.

\section{Geological background}

The Vindhyan Supergroup in central India comprises of mostly shallow marine shale, sandstone and carbonates. The thickness of the succession is about $4500 \mathrm{~m}$. The Vindhyan Supergroup is twotiered separated by a pronounced unconformity.

Keywords. Microbial mat; wavy laminae; black shales; pyrite; teeth and socket structures.

J. Earth Syst. Sci. 115, No. 1, February 2006, pp. 61-66

(C) Printed in India. 


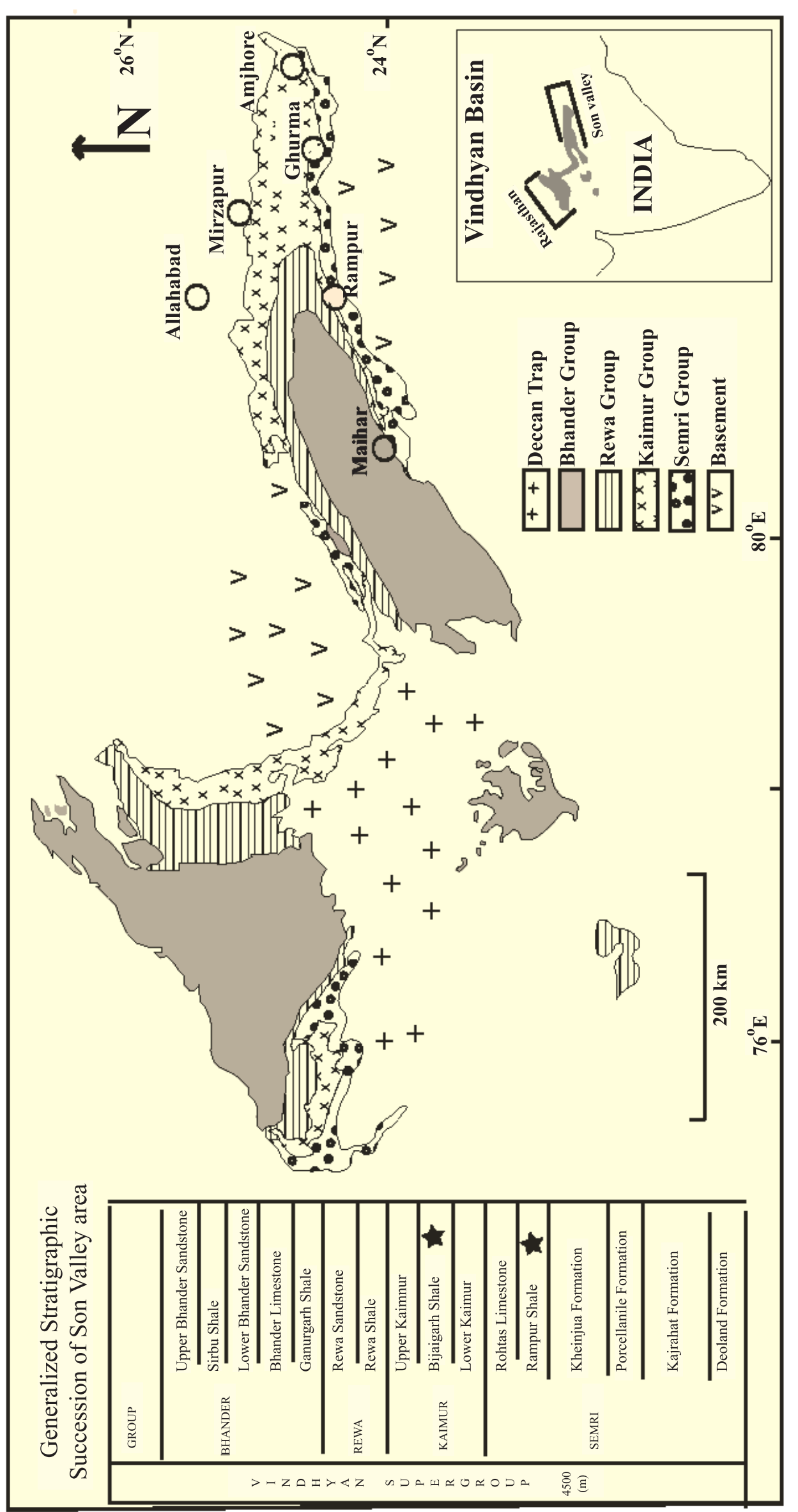

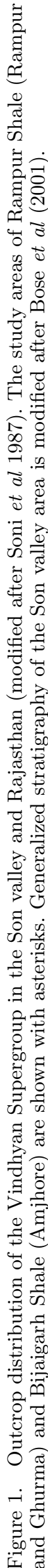


The lower Vindhyans are represented by the Semri Group, whereas Kaimur, Rewa and Bhander Groups constitute the upper Vindhyans. The Rampur and Bijaigarh Shales belong to the Semri and Kaimur Groups respectively. The present study is confined to the Son valley area of the Vindhyan Supergroup. The Rampur Shale has been studied in the Rampur area of Madhya Pradesh and the Ghurma area of Uttar Pradesh; the Bijaigarh Shale has been studied in the Amjhore area of Bihar (figure 1). Both the shale horizons have been inferred to be deposits of shelf below fair-weather wave base (Bose et al 2001).

The laterally persistent Rampur Shale in the studied areas which sharply overlies the Kheinjua Formation, is about $70 \mathrm{~m}$ thick, and consists of black shale with intervening limestone beds (figure 1; Bose et al 2001). The proportion of black shale is highest $(\sim 80 \%)$ in the lower part of the Rampur Shale and decreases towards the top as it grades into the overlying Rohtas Limestone.

The Bijaigarh Shale $(60-70 \mathrm{~m}$ thick in the studied areas) belongs to the Kaimur Group of the upper Vindhyans. In the Amjhore area the Bijaigarh Shale has been subdivided informally into two divisions, e.g., 'bottom shale' and 'top shale'. The bottom shale is micaceous and fissile and contains a smaller amount of pyrite than the top shale. In the bottom shale pyrite occurs mainly in a disseminated form. Persistent sandstone layers $(2 \mathrm{~cm}$ to $12 \mathrm{~cm}$ thick) and isolated sand-filled gutters are interbedded with the bottom shale. Towards the top the frequency of the sandstone beds decreases. The bottom and top shales are separated by a 'pyrite band'. The thickness of the pyrite band ranges from $5 \mathrm{~cm}$ to $1.1 \mathrm{~m}$ (Nair and Ray 1977).

\section{Petrographic observations}

\subsection{General wavy lamination}

Thin section studies of both Rampur and Bijaigarh Shale show wavy and crinkly lamination of clayey and carbonaceous shales facies (figures 2,3). Carbonaceous films of clayey shale facies are very thin, continuous to discontinuous wavy crinkly laminae of variable thickness $(\sim 0.01 \mathrm{~mm}$ to $0.15 \mathrm{~mm})$, and consist of organic matter, with embedded tiny pyrite cubes, whereas the carbonaceous films of the carbonaceous shale facies are thick (up to $0.1 \mathrm{~mm}$ ) and represent mostly continuous wavy crinkly laminae.

These laminae contrast with Phanerozoic carbonaceous shales, which are typically quite even and parallel (Schieber 1986), an observation that suggests a mode of origin that differs from passive

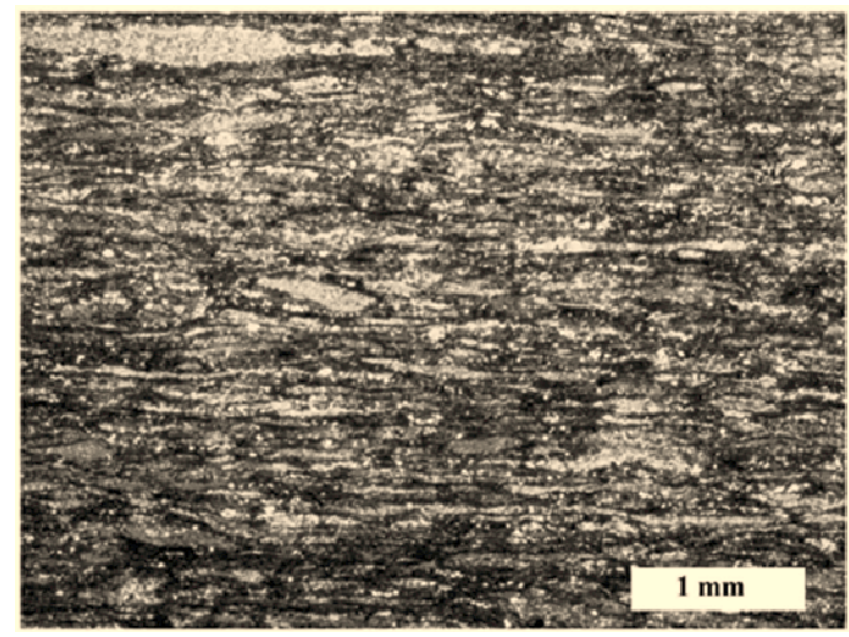

Figure 2. Photomicrograph of Rampur Shale, dominated by clay lenses and clay streaks with thin wavy carbonaceous film (dark color), showing a dominantly wavy fabric.

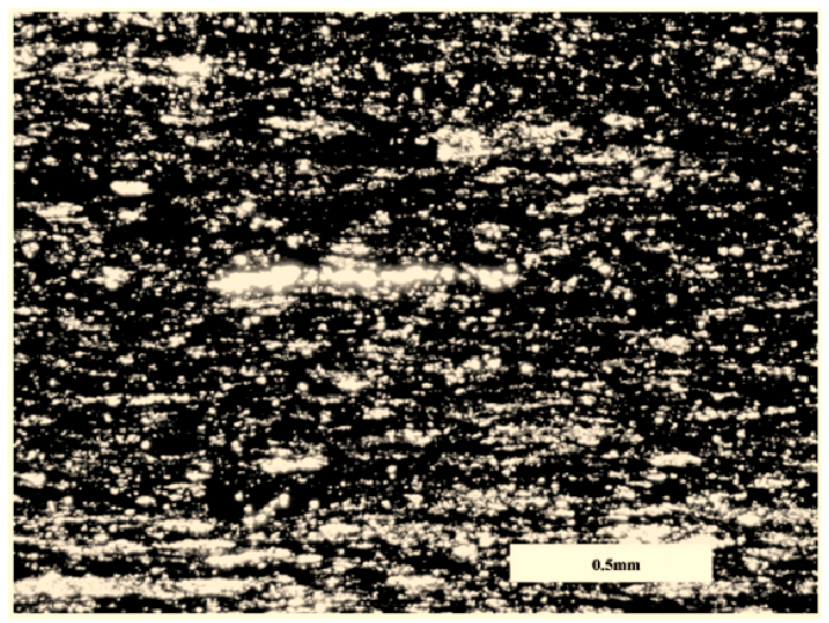

Figure 3. Photomicrograph of Bijaigarh Shale (top of pyrite band), showing a general wavy lamination.

sedimentation of organic material. The observed wavy-crinkly lamination closely resembles microbial mat laminae observed in both modern and ancient microbial mat deposits (Horodyski et al 1977; Krumbein and Cohen 1977; Schieber 1986; Gerdes and Krumbein 1987; O'Brien 1990), and suggests the presence of benthic microbial mats during the deposition of these shales. By themselves, wavy-crinkly laminae are not a reliable indicator of microbial mat deposits (Schieber 1999). This type of laminae could, for example, also be an artifact of differential compaction around clay lenses. Nonetheless, the Bijaigarh Shale also contains wavy lamination in places where there is no clay/silt lenses, suggesting that waviness may be primary and biologically generated (Gerdes and Krumbein 1987). 
(a)

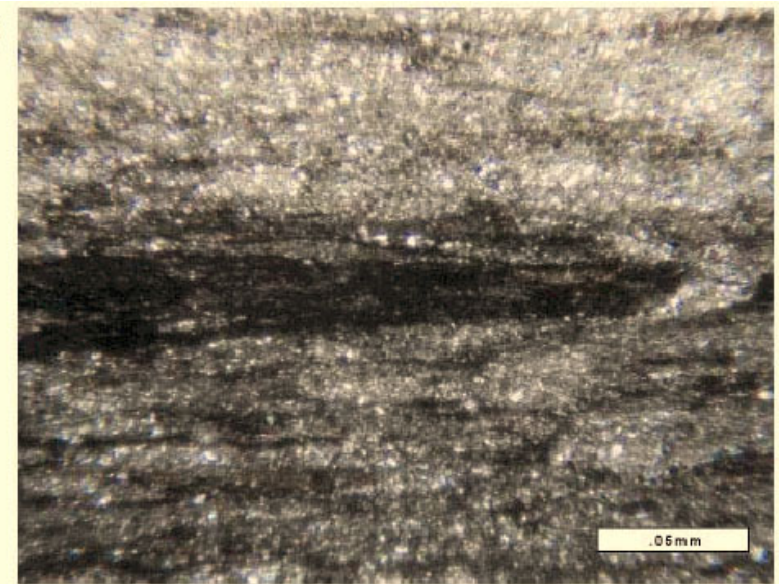

(b)

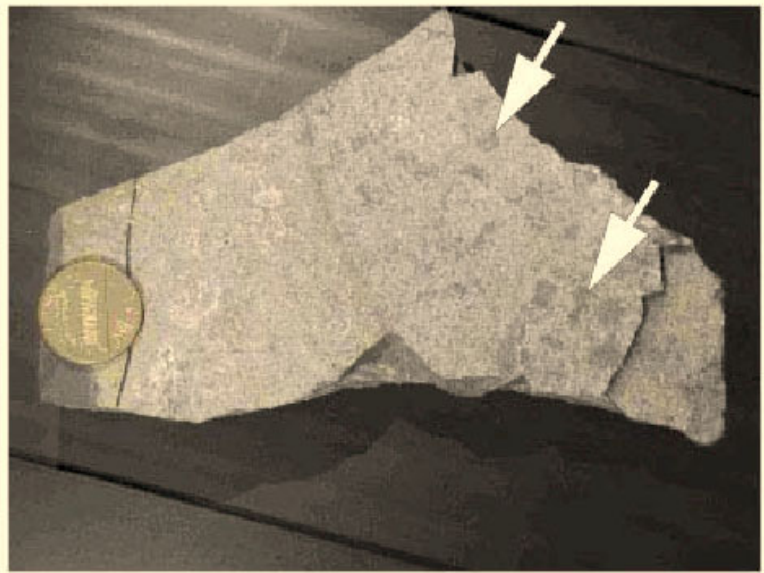

Figure 4. (a) Photomicrograph of folded-over shreds of organic matter which may be an indication of cohesive behavior of organic laminae (Rampur Shale). (b) Handspecimen of the same rock showing shreds of organic matter (up to $20 \mathrm{~mm}$ in diameter) on the bedding plane.

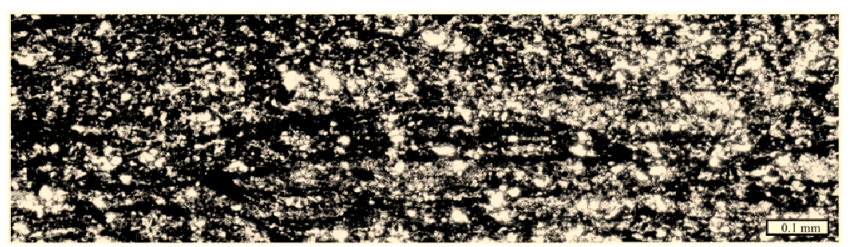

Figure 5. Photomicrograph of Bijaigarh Shale (top of pyrite band), showing rolled-up and folded organic laminae.

\subsection{Contorted and folded thin shreds of organic matter}

These shales contain thin shreds of organic matter that look contorted and folded (figures 4a, b) and rolled-up and folded organic laminae (figure 5).

Firm-doughy and less compactable mat layers show a marked difference in the rheological property and cohesiveness with the contained mud layers, which produced roll-up structures, overfolded mat layers, flipped over mat edges (Schieber 2004). Therefore the observed contorted and folded

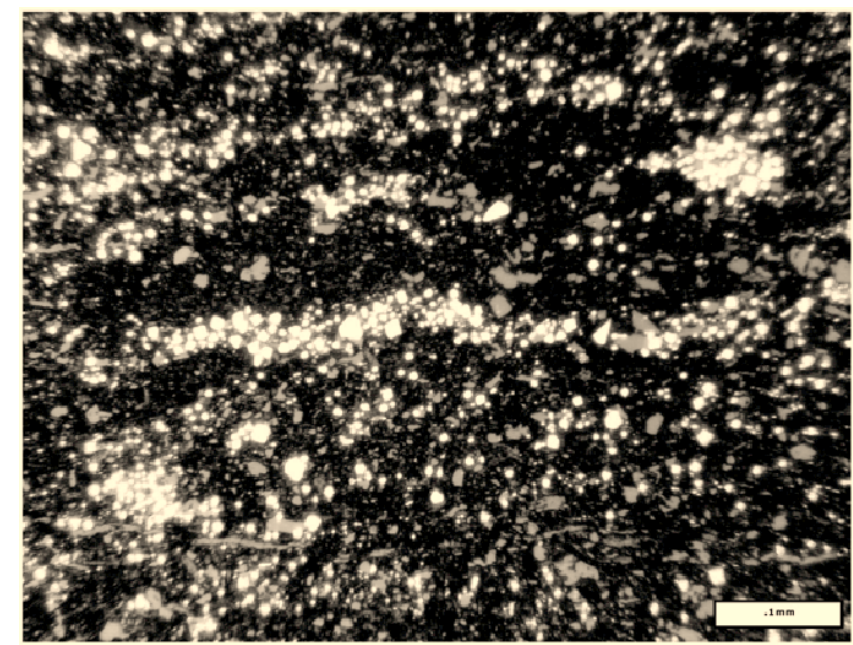

Figure 6. Photomicrograph (under reflected light) of Bijaigarh Shale, showing wavy pyritic laminae.

organic matter in Vindhyan shales may be an indication of cohesive behavior (Schieber 1986, 2004) and be suggestive of microbial mats.

\subsection{Wavy pyritic laminae}

In contrast to Phanerozoic shales, where pyrite tends to be more disseminated, the upper part of Bijaigarh Shale (top of pyrite band) shows wavy pyritic (euhedral to subhedral crystals of pyrite) laminae (bedding parallel) in places (figure 6).

The latter probably represents mineralized microbial mat laminae (e.g., Schieber 1989). The general absence of these lamina types from Phanerozoic shales may reflect the much rarer occurrence of benthic microbial mats in Phanerozoic mud accumulating environments.

\section{4 'Teeth and socket' structure}

SEM observation shows 'teeth and socket' structures, formed by the growth of diagenetic quartz cement between pyrite grains (figure 7).

The 'teeth and socket' structures may provide further support for a microbial mat interpretation of carbonaceous laminae in the Bijaigarh Shale. This type of quartz emplacement is characteristic of very early diagenetic origin, otherwise clays would have been pushed between pyrite grains by compaction as shown in figure 8 . Possibly a matrix of extracellular polymers, produced by microbial mat growth, prevented other sediment grains from getting in between the pyrite grains and was later replaced by quartz. In order to clarify the origin of this interstitial diagenetic quartz, high resolution textural studies are required, possibly coupled with isotopic analyses (oxygen isotopes). 


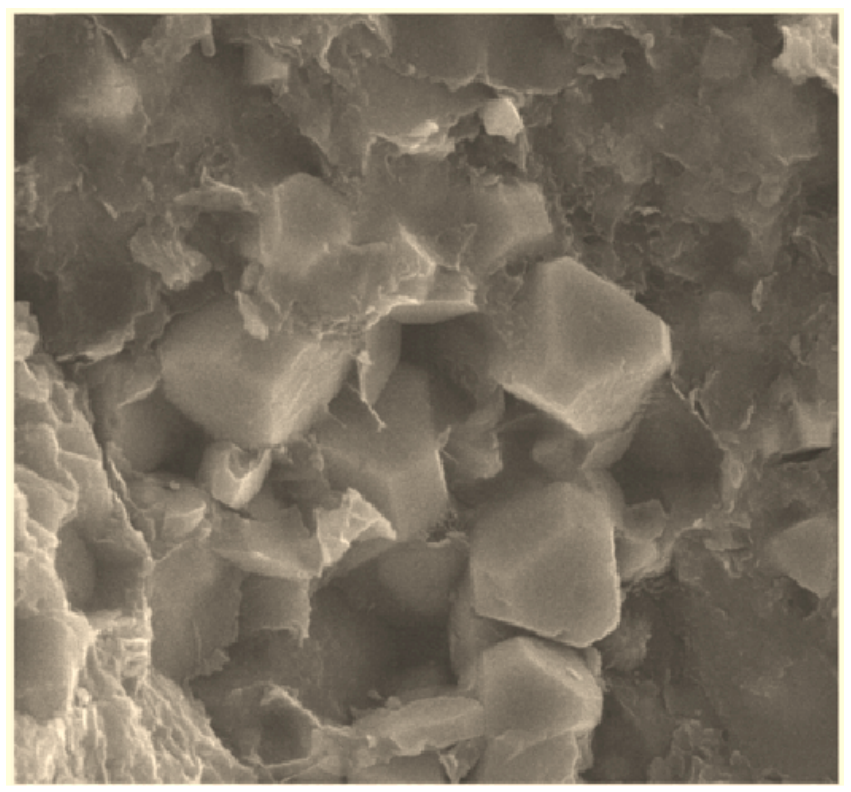

Figure 7. SEM photograph showing 'teeth and socket' structure (Bijaigarh Shale), formed by the growth of diagenetic quartz cement between pyrite grains and suggest a very early diagenetic origin of both pyrite and quartz.

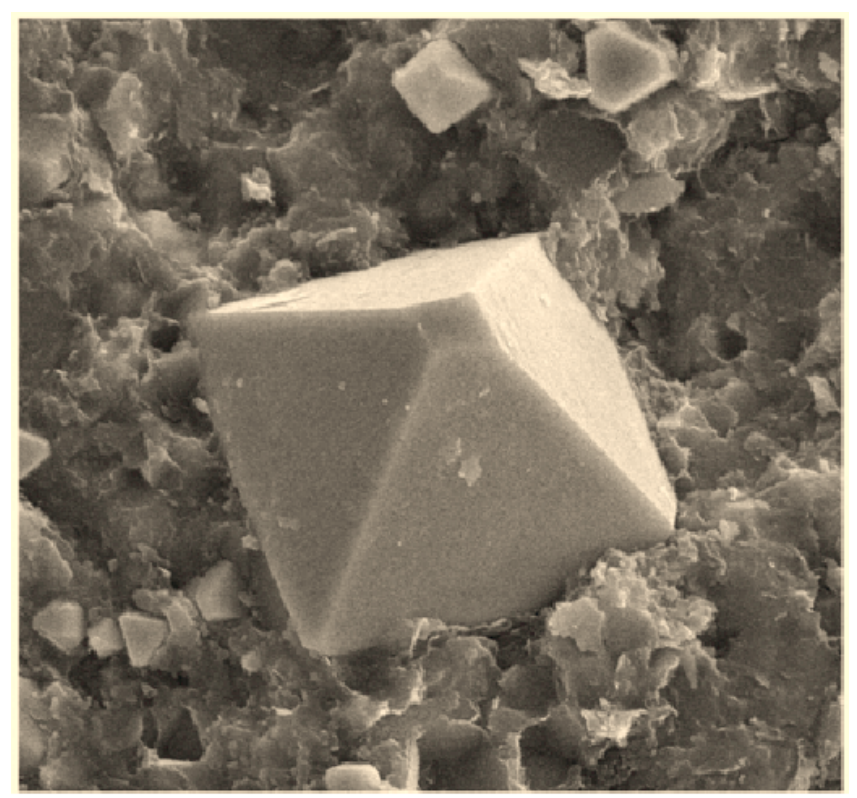

Figure 8. SEM photograph of pyrite crystal showing octahedral habit (Bijaigarh Shale). This pyrite grain is set in a matrix of clay minerals, compared to the 'teeth and socket' structure in figure 7 .

Although, there is no direct evidence of microbial mat presence (e.g., filaments in growth position) in these Vindhyan shales, the presence of wavy crinkly carbonaceous laminae, wavy pyritic laminae, rolled-up and folded carbonaceous flakes and 'teeth and socket' structure and a close (spatial) association with microbially laminated limestone (e.g., Ray et al 2003) in the Rampur Shale makes a strong case for the likely presence of microbial mats. These mats may have been responsible for in situ carbon fixing. Considering their position in the distal and thus most likely deeper portions of the basin, the mats were most likely not inhabited by photosynthetic organisms. In view of the carbonaceous nature of these shales, it is more likely that the mats were dominated by sulfide oxidizing bacteria such as Beggiatoa (Schieber 1999). These mats recycled and fixed planktonic carbon and maintained conditions favoring organic matter preservation in the Bijaigarh Shale.

\section{Conclusions}

Wavy-crinkly laminae, cohesive behavior of carbonaceous laminae, 'teeth and socket' structure, wavy pyritic laminae may be suggestive of microbial mat colonization of the sediment surface during the deposition of the black shales of the Rampur and Bijaigarh Formations of the Vindhyan Supergroup. Mats stabilized sediment, recycled organic matter, and were probably the primary producers. This differs from the majority of Phanerozoic black shales which record planktonic productivity. More research is needed, mainly the carbon and sulfur isotopic and biomarker studies, to know the metabolic pathways and the contribution of different organisms in these black shales, which in a broad sense will help in understanding the Proterozoic source rock formation.

\section{Acknowledgements}

Authors would like to thank the donors of the Petroleum Research Fund, administered by the American Chemical Society (grants 33941-AC8, 38523-AC8 to J Schieber) for support of black shale research, and the reviewers W E Krumbein, C Chakraborty and V S Kale for improving the quality of the manuscript.

\section{References}

Banerjee S and Schieber J 2003 Paleoproterozoic condensed zone sediments in the Kajrahat Formation, Vindhyan Supergroup, Central India; Abstracts with programs Geological Society of America 35173.

Banerjee S and Jeevankumar S 2005 Microbially originated wrinkle structures on sandstone and their stratigraphic context: Paleoproterozoic Koldaha Shale, central India; Sedim. Geol. 176 211-224.

Bose P K, Sarkar S, Chakrabarty S and Banerjee S 2001 Overview of the Meso- to Neoproterozoic evolution of the Vindhyan basin, Central India; Sedim. Geol. 141 395-419.

Gehling J G 1999 Microbial mats in terminal Proterozoic siliciclastics: Ediacaran death masks; Palaios 14 40-57. 
Gerdes G and Krumbein W E 1987 Biolaminated deposits; In: Lecture notes in earth sciences (eds) Bhattacharji S, Friedman G M, Neugebauer H J, Seilacher A (Berlin: Springer-Verlag), 183p.

Hagadorn J W, Pflüger F and Bottjer D J 1999 Unexplored microbial worlds; Palaios 14 73-85.

Horodyski R J, Bloeser B and Von Der Haar S 1977 Laminated algal mats from a coastal lagoon, Laguana Mormona, Baja California, Mexico; J. Sed. Pet. 47 680-696.

Krumbein W E and Cohen Y 1977 Primary production, mat formation and lithification: Contribution of oxygenic and facultative anoxygenic cyanobacteria; In: Fossil Algae (ed) E Flügel (New York: Springer-Verlag), pp. 37-56.

Nair N G K and Ray A 1977 Syndepositional and diagenetic features in the Pyrite Ores of Amjhore, Bihar, India; Mineral. Deposita 12 151-154.

O'Brien N R 1990 Significance of lamination in the Toarcian (Lower Jurassic) shales from Yorkshire, Great Britain; Sedim. Geol. 67 25-34.

Pflüger F 1999 Matground Structures and Redox Facies; Palaios 14 25-39.

Ray J S, Veizer J and Davis W J 2003 C, O, Sr and Pb isotope systematics of carbonate sequences of the Vindhyan Supergroup, India: age, diagenesis, correlations and implications for global events; Precamb. Res. 121 $103-140$

Sarkar S, Banerjee S and Eriksson P G 2004 Microbial mat features in sandstone illustrated; In: The Precambrian earth: tempos and events (eds) Eriksson P G, Altermann W, Nelson D R, Mueller W U, Catuneanu O (Amsterdam: Elsevier), pp. 673-675.
Sarkar S, Banerjee S, Eriksson P G and Catuneanu O 2005 Microbial mat control on siliciclastic Precambrian sequence Stratigraphic architecture: Examples from India; Sedim. Geol. 176 195-209.

Schieber J 1986 The possible role of benthic microbial mats during the formation of carbonaceous shales in shallow Mid-Proterozoic basins; Sedimentology $\mathbf{3 3}$ $521-536$.

Schieber J 1989 Pyrite mineralization in microbial mats from the Mid-Proterozoic Newland Formation, Belt Supergroup, Montana, U.S.A; Sedim. Geol. 64 79-90.

Schieber J 1999 Microbial mats in terrigenous clastics: The challenge of identification in the rock record; Palaios 14 $3-12$.

Schieber J 2004 Microbial mats in the siliciclastic rock record: a summary of diagnostic features. In: The Precambrian earth: tempos and events (eds) Eriksson P G, Altermann W, Nelson D R, Mueller W U, Catuneanu O (Amsterdam: Elsevier), pp. 663-673.

Schwarz H U, Einsele G and Herm D 1975 Quartz sandy, grazing contoured stromatolites from coastal embayments of Mauretania, West Africa; Sedimentology 22 539-561.

Seilacher A and Pflüger F 1994 From biomats to benthic agriculture: A biohistoric revolution; In: Biostabilization of sediments: Bibliotheks und Informationssystem der Carl von Ossietzky Universität Oldenburg (BIS) (eds) Krumbein W E, Paterson D M, Stal L J (Germany: Oldenburg), pp. 97-105.

Soni M K, Chakraborty S and Jain V K 1987 Vindhyan Supergroup - a review; Geol. Soc. India Memoir 6 $87-138$ 